\title{
Immune Status of Leukemia Patients
}

\author{
Y. Kaneko ${ }^{1}$, H. Miyakoshi ${ }^{2}$, Y. Aoyagi ${ }^{3}$, and T. Aoki ${ }^{2}$
}

\section{A. Introduction}

The immune status of patients with hematologic disorders, especially various leukemias, may fluctuate according to the clinical course, e.g., acute phase, chronic phase, remission, and smoldering stage. In particular, since leukemia involves a variety of white blood cells, including subsets of lymphocytes, immunologic function as well as general function should be greatly modified, influencing the host defense mechanisms [1]. In this study, nonspecific and specific immune activities of patients with various hematologic disorders were investigated in the different phases of disease.

\section{B. Nonspecific Immune Activity}

NK activity of peripheral mononuclear cells (PM-NC) against human myeloid K562 cells generally fell in patients with almost all kinds of hematologic disorders and even with solid tumors or chronic infections diseases (Fig. 1). On the contrary, spontaneous DNA synthesis of PM-NC tends to be elevated in patients with various leukemias, including acute myelogenous

1 Pharmaceutical Department, Ajinomoto Company, 1-5-8 Kyobashi, Chuoku, Tokyo 104, Japan

2 Research Division, Shinrakuen Hospital, 1-27 Nishiariakecho, Niigata 950-21, Japan

3 1st Department of Internal Medicine, Gunma University School of Medicine, 3-39-22 Shohwacho, Maebashi 371, Japan leukemia (AML), acute lymphocytic leukemia (ALL), and chronic myelogenous leukemia (CML), and with polycythemia vera, primary myelofibrosis, and primary thrombocythemia (Fig. 1). However, PM$\mathrm{NC}$ from patients with aplastic anemia, paroxysmal nocturnal hemoglobinuria, and solid tumors showed a decrease in spontaneous DNA synthesis. In detail, PM-NC from patients with AML or ALL showed relatively high NK activity, even below the normal range in complete remission, but relatively low levels of spontaneous DNA synthesis in complete remission (Fig. 2).

When PM-NC from patients with leukemias were stimulated with three different mitogens, PHA, SPL (staphage lysate), and Con-A, mitogen-induced DNA synthesis generally fell, except for slight elevation in the complete remission of AML and ALL (Fig. 3). Particularly, when stimulated with PHA, these PM-NC showed clear elevation in PHA-induced DNA synthesis.

\section{Specific Immune Activity}

As summarized in Table 1, one leukemia patient, four lymphoma patients, and two patients with solid tumors were investigated for autochthonous cell-mediated cytotoxicity in comparison with NK activity of their PM-NC against K562 cells. PM-NC from patients with ATL or Burkitt's malignant lymphomas (patients 1 and 2) did not lyse their own tumor cells by either direct killer $\mathrm{T}$ cell-mediated cytotoxicity or antibody-dependent cellular cytotoxicity 


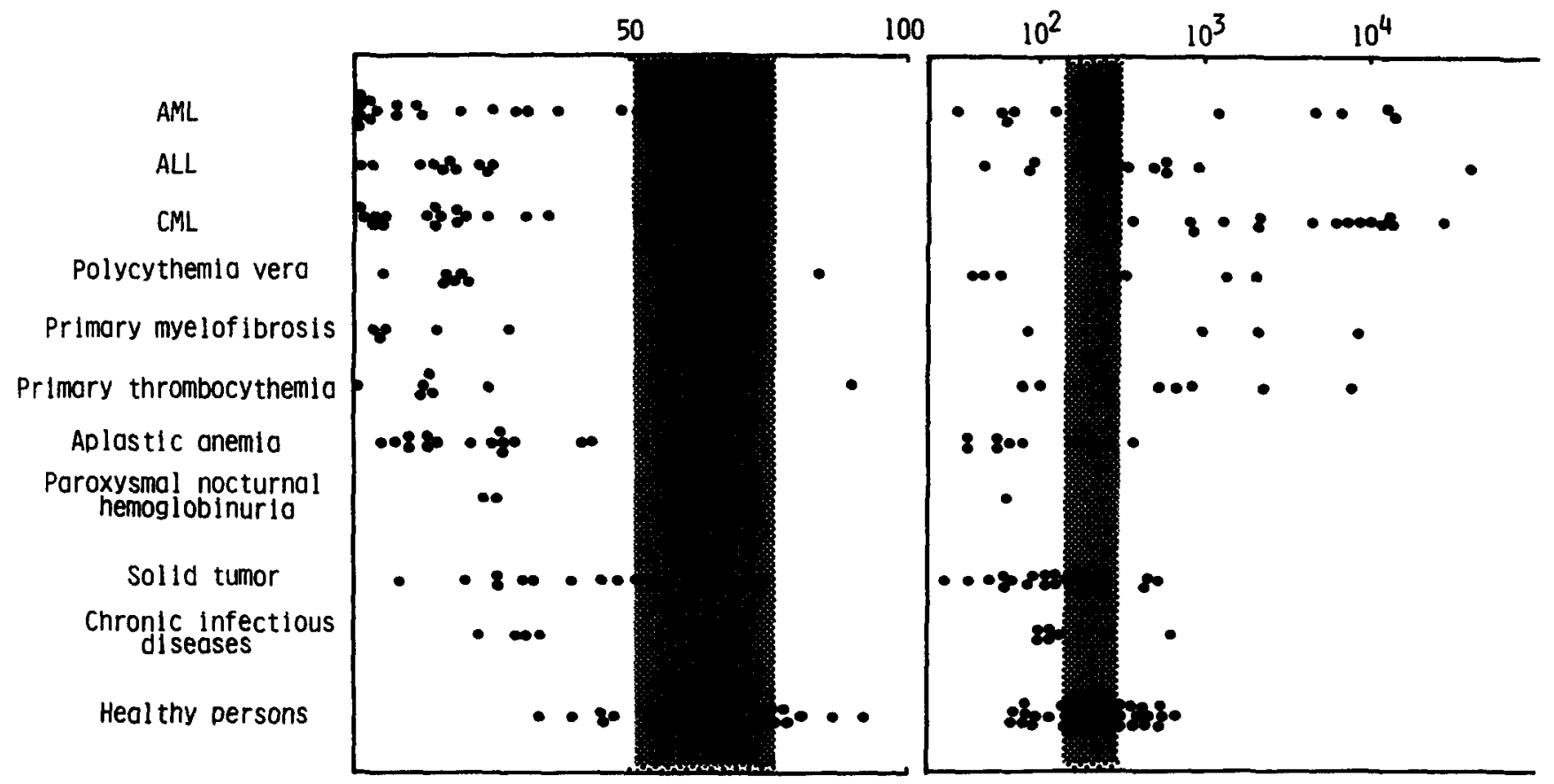

Fig. 1. NK activity and ${ }^{3} \mathrm{H}-\mathrm{TdR}$ incorporation of peripheral mononuclear cells from leukemia patients

(ADCC) (Table 2), but showed significant NK activity. PM-NC from patients 3 and 4 with malignant lymphoma were positive for both ADCC and NK activity. Interestingly, PM-NC from patient 5 with $\mathrm{T}$ cell malignant lymphoma were negative for

Fig. 2. NK activity and ${ }^{3} \mathrm{H}-\mathrm{TdR}$ incorporation of peripheral mononuclear cells from leukemia patients in various phases cell-mediated cytotoxicity (CMC) against malignant cells from the patient's own inguinal lymph nodes and positive for CMC against malignant cells from the patient's own neck lymph node, but positive for NK activity, suggesting a difference in the antigen specificity of malignant cells located in the different lymph nodes of a given patient. Another interesting fact is that PMNC from patient 7 with paraganglioma were positive for both $\mathrm{CMC}$ and NK activity, but mononuclear cells from the malignant tissue were positive for $\mathrm{CMC}$ against the patient's own malignant cells, but negative for NK activity. These results

NK cell octivity ( $\bar{x}$ cytolysis) Spontaneous DNA synthesis (cDm)

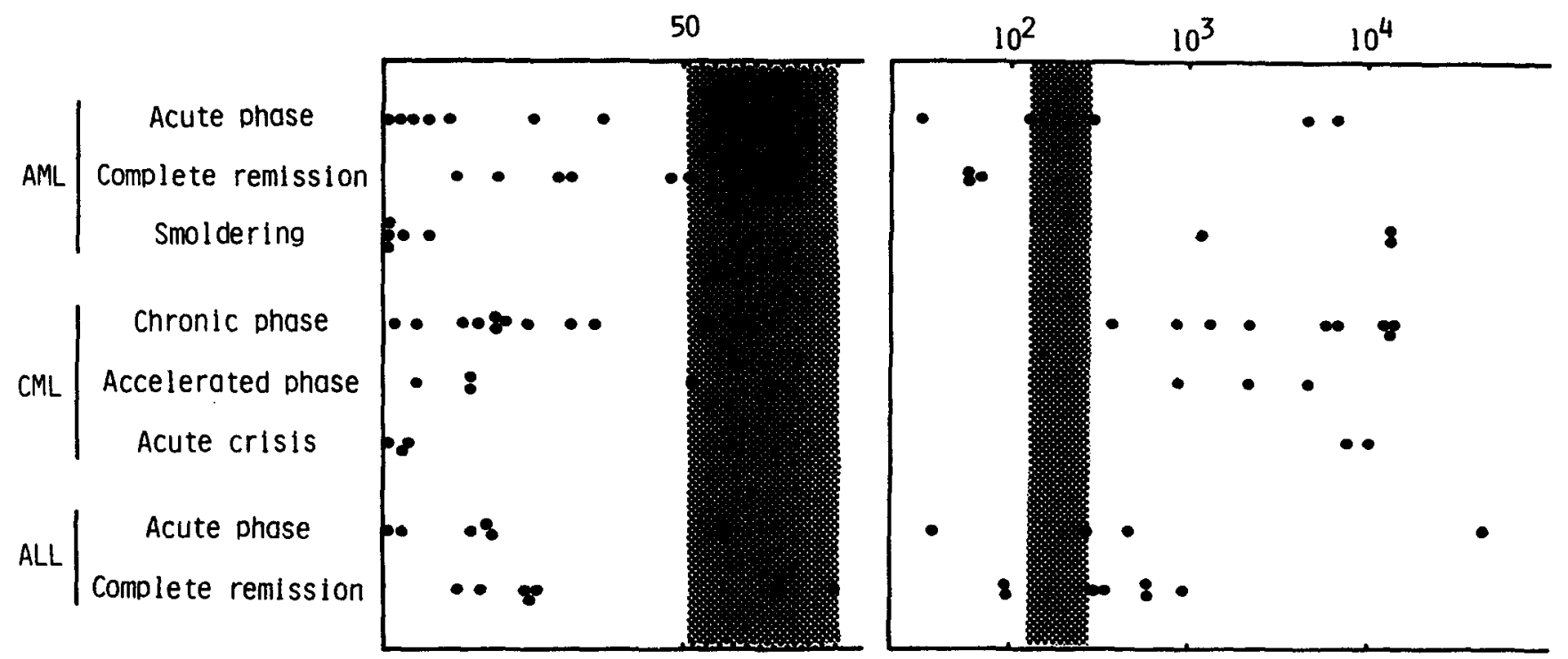


suggest that specific, cytotoxic effector cells selectively penetrated into the malignant tissue, or that, since morphologically these cells are large granular lymphocytes, there may be at least two different NK cell subsets one of which possesses such a specific CMC, but no NK activity and another which possesses NK activity, but no specific $\mathrm{CMC}$ [2].

In the light of this specific CMC, the following important observations seem appropriate: (a) tumor cells in different re-

Fig. 3. Mitogen-induced DNA synthesis of peripheral mononuclear cells from leukemia patients in various phases gional foci of one patient possess individual tumor-specific cell surface antigens; and (b) at least two different subgroups of cytotoxic mononuclear cells, even in the same subset, separately recognize individual cell surface antigens. In future, therefore, the immunotherapy of cancer might be achieved by combination of various specific antibodies, various effector cells of the subset, or several subsets of effector cells.

\section{Remarks}

The spontaneous DNA synthesis of PM-NC from most patients with hematologic disorders was higher than the normal level.
PHA-Induced DNA synthesis $\left(x 10^{4} \mathrm{cpm}\right)$

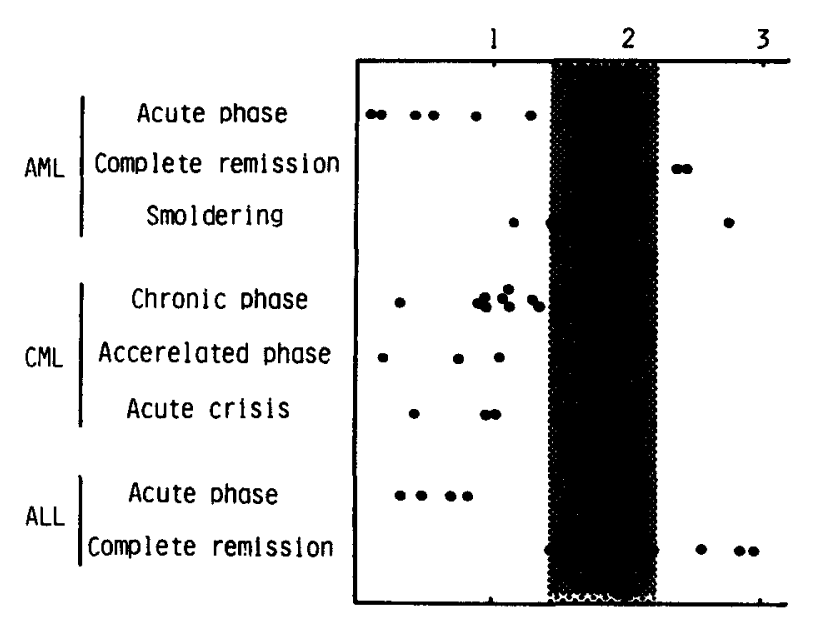

SPL-induced DNA synthes Is $\left(\times 10^{4} \mathrm{cpm}\right)$

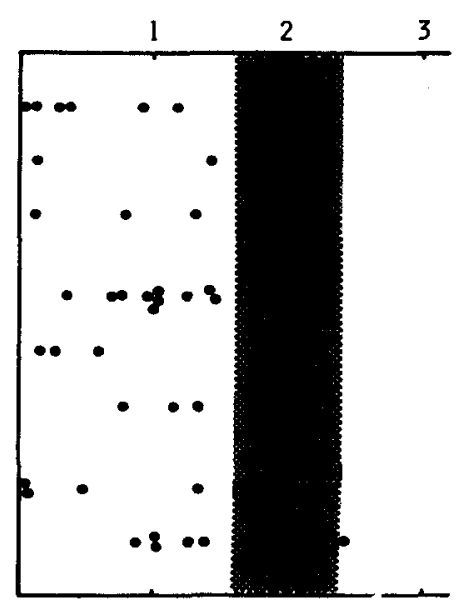

Con A-Induced DNA synthesis $\left(\times 10^{4} \mathrm{cpm}\right)$

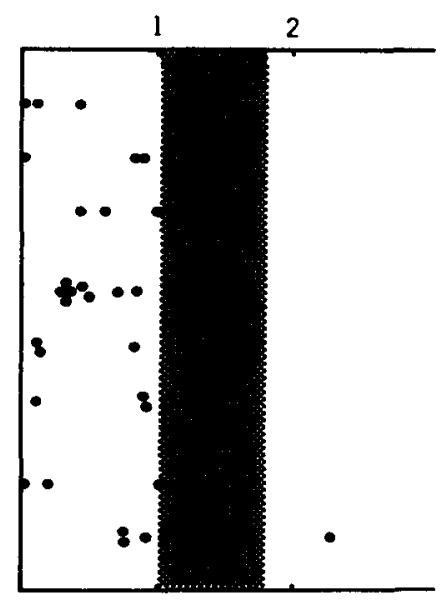

Table 1. Cell-mediated immunity in the autochthonous system of patients with malignant diseases

\begin{tabular}{lllll}
\hline $\begin{array}{l}\text { Patient } \\
\text { No. }\end{array}$ & Diagnosis & $\begin{array}{l}\text { Source of target } \\
\text { malignant cells }\end{array}$ & $\begin{array}{l}\text { Cell-mediated } \\
\text { cytotoxicity } \\
\text { to tumor cells }\end{array}$ & $\begin{array}{l}\text { NK activity } \\
\text { to K562 } \\
\text { cells }\end{array}$ \\
\hline 1 & $\begin{array}{l}\text { Adult T-cell leukemia } \\
\text { Malignant lymphoma } \\
\text { (Burkitt's) }\end{array}$ & $\begin{array}{l}\text { Subcutaneous tumor of leg } \\
\text { Neck lymph node }\end{array}$ & $\begin{array}{l}(-) \\
(-)\end{array}$ & $(+)$ \\
3 & $\begin{array}{l}\text { Malignant lymphoma } \\
\text { Malignant lymphoma }\end{array}$ & & $(+)($ ADCC) & $(+)$ \\
4 & $\begin{array}{l}\text { Malignant lymphoma } \\
\text { (T cell type) }\end{array}$ & $\begin{array}{l}\text { Neck lymph node } \\
\text { Inguinal lymph nodes }\end{array}$ & $\begin{array}{l}(+)(\text { Killer T?) } \\
(-)\end{array}$ & $(+)$ \\
6 & $\begin{array}{l}\text { Metastatic squamous } \\
\text { cell carcinoma }\end{array}$ & Neck lymph node & $( \pm)$ (Killer T?) & $(+)$ \\
7 & Paraganglioma & Subcutaneous tumor of arm & $(+)$ (Effector cell & $(-)$ \\
in tumor cells) & $(+)$ \\
& & & $(+)$ (PM-NC) & $(+)$ \\
\hline
\end{tabular}


Table 2. Killer activity of peripheral mononuclear cells (PM-NC) from patients with malignant diseases

\begin{tabular}{|c|c|c|c|c|c|c|c|c|}
\hline \multirow[t]{4}{*}{ Target cells } & \multirow[t]{4}{*}{ Plasma } & \multicolumn{7}{|l|}{ PM-NC donors } \\
\hline & & \multirow{3}{*}{$\begin{array}{l}\text { Adult T-cell } \\
\text { leukemia } \\
\text { (in remission) } \\
\text { Patient } 1\end{array}$} & \multicolumn{5}{|c|}{ Malignant lymphoma } & \multirow{3}{*}{$\begin{array}{l}\text { Metastatic } \\
\text { squamous cell } \\
\text { carcinoma } \\
\text { Patient-6 }\end{array}$} \\
\hline & & & \multirow{2}{*}{$\begin{array}{l}\mathrm{Pa}- \\
\text { tient } \\
2\end{array}$} & \multirow{2}{*}{$\begin{array}{l}\mathrm{Pa}- \\
\text { tient } \\
3\end{array}$} & \multirow{2}{*}{$\begin{array}{l}\mathrm{Pa}- \\
\text { tient } \\
4\end{array}$} & \multicolumn{2}{|c|}{ Patient 5} & \\
\hline & & & & & & $\begin{array}{l}\text { Neck } \\
\text { tumo }\end{array}$ & $\begin{array}{l}\text { Inguinal } \\
\text { r tumor }\end{array}$ & \\
\hline $\begin{array}{l}\text { Patient's own } \\
\text { tumor cells }\end{array}$ & $\begin{array}{l}\text { Patient's own } \\
\text { Healthy donor } \\
\text { Pooled AB } \\
\text { Fetal calf } \\
\text { serum }\end{array}$ & $\begin{array}{l}0.9^{\mathrm{a}} \\
0 \\
\text { N.D. } \\
0.9\end{array}$ & $\begin{array}{r}3.7 \\
9.1 \\
10.3 \\
\text { N.D. }\end{array}$ & $\begin{array}{r}12.1 \\
-2.5 \\
5.4 \\
\text { N.D. }\end{array}$ & $\begin{array}{r}16.7 \\
-13.4 \\
-15.4 \\
-22.9\end{array}$ & $\begin{array}{r}43.3 \\
25.5 \\
35.1 \\
1.4\end{array}$ & $\begin{array}{l}7.0 \\
0 \\
5.6 \\
15.5\end{array}$ & $\begin{array}{r}9.1 \\
21.4 \\
19.8 \\
\text { N.D. }\end{array}$ \\
\hline K562 cells & $\begin{array}{l}\text { Patients own } \\
\text { Healthy donor } \\
\text { Pooled AB } \\
\text { Fetal calf } \\
\text { serum }\end{array}$ & $\begin{array}{l}51.9 \\
59.3 \\
\text { N.D. } \\
\text { N.D. }\end{array}$ & $\begin{array}{l}25.6 \\
30.1 \\
28.7 \\
\text { N.D. }\end{array}$ & $\begin{array}{l}70.3 \\
72.8 \\
53.9 \\
\text { N.D. }\end{array}$ & $\begin{array}{r}79.6 \\
91.3 \\
67.2 \\
\text { N.D. }\end{array}$ & & $\begin{array}{l}7.5 \\
1.9 \\
0.2 \\
0.0\end{array}$ & $\begin{array}{l}79.6 \\
\text { N.D. } \\
77.5 \\
\text { N.D. }\end{array}$ \\
\hline
\end{tabular}

a Percentage cytolysis (target: $\mathrm{PMNC}=1: 40$ )

b Not done

This suggests that PM-NC with normal morphology from these patients may be functionally abnormal like those in the preleukemic stage, since PM-NC from most carriers of human $T$ cell leukemia/lymphoma virus type I (HTLV-I) showed increased spontaneous DNA synthesis without malignant transformation [3]. HTLV-I infection may also change the function of PM-NC in HTLV-I carriers [4]. Even though no morphological changes occurred in the PM-NC, DNA synthesis became maximal so that a further increase in DNA synthesis was not induced by mitogen stimulation.

In terms of spontaneous DNA synthesis and NK activity of PM-NC, smoldering AML and CML are quite similar to each other, as described. Accordingly, these two diseases might be considered as one, especially from a nonspecific immunologic point of view [2]. The specificity of cell surface antigens, humoral antibodies, and $\mathrm{CMC}$ is very complicated indeed. Thus, diagnosis and treatment of leukemias by immunologic methods are extremely hard to establish. In particular, the immunotherapy of malignancies is not simple, but should be investigated from sophisticated and multiple standpoints.

\section{References}

1. Aoki T, Miyakoshi H, Horikawa Y, Shibata A, Aoyagi Y, Mizukoshi M (1982) Interaction between interferon and natural killer cells in humans after administration of immunomodulating agents. In: Herberman RB (ed) NK cells and other natural effector cells. Academic, New York, pp 1291-1302

2. Aoki T, Shibata A, Aoyagi Y, Miyakoshi H (1982) Immune status in leukemia patients. In: Yohn DS, Blakeslee JR (eds) Advances in comparative leukemia research 1981. Elsevier North Holland, Amsterdam, pp 547-549

3. Miyakoshi H, Aoki T (1984) Immunological study of HTLV-I-infected hosts. In: Aoki T, Tsubura E, Urushizaki I (eds) Manipulation of host defence mechanisms. Excerpta Medica, Amsterdam, pp 152-161

4. Miyakoshi $H$, Koide $H$, Aoki $T$ (1984) In vitro antibody-dependent cellular cytotoxicity against human T-cell leukemia/lymphoma virus (HTLV)-producing cells. Int $J$ Cancer $33: 287-291$ 